\title{
Microbial composition and diversity of an upland red soil under long-term fertilization treatments as revealed by culture-dependent and culture-independent approaches
}

\author{
Ji-Zheng He • Yong Zheng • Cheng-Rong Chen • \\ Yuan-Qiu He $\cdot$ Li-Mei Zhang
}

Received: 28 December 2007 / Accepted: 24 June 2008 / Published online: 20 August 2008

(C) Springer-Verlag 2008

\begin{abstract}
Background, aim, and scope Fertilization is an important agricultural practice for increasing crop yields. In order to maintain the soil sustainability, it is important to monitor the effects of fertilizer applications on the shifts of soil microorganisms, which control the cycling of many nutrients in the soil. Here, culture-dependent and cultureindependent approaches were used to analyze the soil bacterial and fungal quantities and community structure under seven fertilization treatments, including Control, Manure, Return (harvested peanut straw was returned to the plot), and chemical fertilizers of NPK, NP, NK, and PK. The objective of this study was to examine the effects on soil microbial composition and diversity of long-term organic and chemical fertilizer regimes in a Chinese upland red soil.

Materials and methods Soil samples were collected from a long-term experiment station at Yingtan $\left(28^{\circ} 15^{\prime} \mathrm{N}, 116^{\circ} 55^{\prime} \mathrm{E}\right)$,
\end{abstract}

J.-Z. He $(\bowtie) \cdot$ Y. Zheng $\cdot$ L.-M. Zhang

State Key Laboratory of Urban and Regional Ecology,

Research Center for Eco-environmental Sciences,

Chinese Academy of Sciences,

Beijing 100085, China

e-mail: jzhe@rcees.ac.cn

C.-R. Chen

Centre for Forestry \& Horticultural Research,

School of Science, Griffith University,

Nathan 4111,

Queensland, Australia

\section{Y. Zheng}

Graduate University, Chinese Academy of Sciences, Beijing 100049, China

Y.-Q. He

Institute of Soil Science, Chinese Academy of Sciences,

Nanjing 210008, China
Jiangxi Province of China. The soil samples $(0-20 \mathrm{~cm})$ from four individual plots per treatment were collected. The total numbers of culturable bacteria and fungi were determined as colony forming units (CFUs) and selected colonies were identified on agar plates by dilution plate methods. Moreover, soil DNAs were extracted and bacterial 16S rRNA genes and fungal 18S rRNA genes were polymerase chain reaction amplified, and then analyzed by denaturing gradient gel electrophoresis (DGGE), cloning, and sequencing.

Results The organic fertilizers, especially manure, induced the least culturable bacterial CFUs, but the highest bacterial diversity ascertained by DGGE banding patterns. Chemical fertilizers, on the other hand, had less effect on the bacterial composition and diversity, with the NK treatment having the lowest CFUs. For the fungal community, the manure treatment had the largest CFUs but much fewer DGGE bands, also with the NK treatment having the lowest CFUs. The conventional identification of representative bacterial and fungal genera showed that long-term fertilization treatments resulted in differences in soil microbial composition and diversity. In particular, $42.4 \%$ of the identified bacterial isolates were classified into members of Arthrobacter. For fungi, Aspergillus, Penicillium, and Mucor were the most prevalent three genera, which accounted for $46.6 \%$ of the total identified fungi. The long-term fertilization treatments resulted in different bacterial and fungal compositions ascertained by the culture-dependent and also the culture-independent approaches.

Discussion It was evident that more representative fungal genera appeared in organic treatments than other treatments, indicating that culturable fungi were more sensitive to organic than to chemical fertilizers. A very notable finding was that fungal CFUs appeared maximal in organic manure treatments. This was quite different from the 
bacterial CFUs in the manure, indicating that bacteria and fungi responded differently to the fertilization. Similar to bacteria, the minimum fungal CFUs were also observed in the NK treatment. This result provided evidence that phosphorus could be a key factor for microorganisms in the soil. Thus, despite the fact that culture-dependent techniques are not ideal for studies of the composition of natural microbial communities when used alone, they provide one of the more useful means of understanding the growth habit, development, and potential function of microorganisms from soil habitats. A combination of culture-dependent and culture-independent approaches is likely to reveal more complete information regarding the composition of soil microbial communities.

Conclusions Long-term fertilization had great effects on the soil bacterial and fungal communities. Organic fertilizer applications induced the least culturable bacterial CFUs but the highest bacterial diversity, while chemical fertilizer applications had less impact on soil bacterial community. The largest fungal CFUs were obtained, but much lower diversity was detected in the manure treatment. The lowest bacterial and also fungal CFUs were observed in the NK treatment. The long-term fertilization treatments resulted in different bacterial and fungal compositions ascertained by the culture-dependent and also the culture-independent approaches. Phosphorus fertilizer could be considered as a key factor to control the microbial CFUs and diversity in this Chinese upland red soil.

Recommendations and perspectives Soil fungi seem to be a more sensitive indicator of soil fertility than soil bacteria. Since the major limitation of molecular methods in soil microbial studies is the lack of discrimination between the living and dead, or active and dormant microorganisms, both culture-dependent and culture-independent methods should be used to appropriately characterize soil microbial diversity.

Keywords Bacterial and fungal diversity . Culture-dependent method · Denaturing gradient gel electrophoresis $\cdot$ Long-term experiment $\cdot$ Organic fertilizer $\cdot$ Red soil

\section{Background, aim, and scope}

Soil quality has been used as an important indicator of ecosystem health and sustainability of agroecosystems. It can be assessed using soil physical, chemical, and biological approaches (Karlen et al. 2003). Soil microbial composition and diversity have been considered to be one of the most sensitive biological indicators for measuring soil quality (Kennedy 1999). Traditionally, soil microbial communities are investigated using methods based on isolating and culturing the microorganisms. These culture- dependent approaches to characterize microbial communities have built-in biases in the isolation of microorganisms. Recent attempts have been made to develop new culture media to maximize the recovery of diverse microbial groups (Davis et al. 2005; Vieira and Nahas 2005). This is particularly the case for studies of soil health. There are numerous examples where culture-dependent methods were used to investigate the impacts of heavy metals, organic contaminants and herbicides on the diversity of the soil culturable bacterial community due both to the suppression of some bacterial groups and the enrichment of some contaminant-resistant bacterial taxa (Thompson et al. 1998; Ellis et al. 2001, 2003; Ratcliff et al. 2006). Ellis et al. (2003) indicated that the readily culturable bacteria could be the largest, most active prokaryotes in a given sample and so provide a useful, rapid assessment of biological responses to heavy metal pollution. Thus, although culturedependent approaches of microbial community analysis are often criticized for their selectivity, it is perhaps this discrimination that makes them useful for determining the impact of anthropogenic activity.

Culture-independent methods have been used recently in preference to traditional isolation techniques for microbial community analysis, including denaturing gradient gel electrophoresis (DGGE), temperature gradient gel electrophoresis (TGGE), or temporal temperature gel electrophoresis (TTGE) methods (Muyzer et al. 1993; Torsvik et al. 1998; Muyzer 1999; Kirk et al. 2004; Kostanjsek et al. 2005). These culture-independent techniques have proved powerful in detecting soil microbial composition and diversity, providing an insight into the response of soil ecosystems to environmental changes or anthropogenic disturbance. As an important anthropogenic management practice for crop yields, fertilization can also change the abundance and composition of soil functional microorganisms such as ammonia-oxidizers, which play an important role in the nitrogen cycle (He et al. 2007; Shen et al. 2008). Therefore, given the nutrient cycling processes in soil influence global climate change (Xu and Chen 2006) or only maintain the soil sustainability, it is important to monitor the effects of fertilizer application on soil microbial composition and diversity.

Many studies had focused on the influence of long-term fertilizer applications on soil physical properties (PernesDebuyser and Tessier 2004), soil fertility (Mallarino and Borges 2006), and soil organic matter, and crop yield (Cai and Qin 2006). The biological component of soils usually responds more rapidly to changing soil conditions than does either chemical or physical properties (Simek et al. 1999). Microbial activities were found to be promoted by organic fertilizers, such as swine or cow manure, and even biowaste compost (Simek et al. 1999; Enwall et al. 2005; Palmroth et al. 2006). Application of chemical fertilizers 
has also been shown to have effects on soil microbial biomass (Herai et al. 2006; Zhong and Cai 2007). However, there are not so many studies investigating together the bacterial and fungal composition and diversity of soils receiving long-term fertilizer applications. The objective of this study was to examine the effects on soil microbial diversity of long-term organic and chemical fertilizer applications by using the culture-dependent and cultureindependent approaches.

\section{Materials and methods}

\subsection{Site description and soil sampling}

Soil samples were collected from the Red Soil Ecology Experimental Station of Chinese Academy of Sciences (CAS) at Yingtan $\left(28^{\circ} 15^{\prime} \mathrm{N}, 116^{\circ} 55^{\prime} \mathrm{E}\right)$, southeastern Jiangxi Province of China. This region has a typical subtropical monsoon climate with a mean annual precipitation of $1,785 \mathrm{~mm}$ and a mean annual temperature of $17.8^{\circ} \mathrm{C}$. The soil was derived from quaternary red clay and classified as Hapludults. The land utilization was one peanut with fallow in winter, and fertilizers were applied annually since 1989. Seven fertilization treatments with four replications for each treatment were as follows: Control of organic fertilizer, no organic fertilizer, only a small quantity of chemical fertilizer including $60 \mathrm{~kg} \mathrm{~N}^{-1}$ plus $20 \mathrm{~kg} \mathrm{P} \mathrm{ha}^{-1}$ plus $59 \mathrm{~kg} \mathrm{~K} \mathrm{ha}^{-1}(\mathrm{CON})$; two organic fertilizer treatments including Manure (CON plus 15,000 kg swine manure) and Return (CON plus all the harvested peanut straw back to the field); four chemical fertilizer treatments including NPK (120 kg N ha ${ }^{-1}$ plus $40 \mathrm{~kg} \mathrm{P} \mathrm{ha}^{-1}$ plus $118 \mathrm{~kg} \mathrm{~K} \mathrm{ha}^{-1}$ ), NP $\left(120 \mathrm{~kg} \mathrm{~N} \mathrm{ha}^{-1}\right.$ plus $\left.40 \mathrm{~kg} \mathrm{P} \mathrm{ha}^{-1}\right)$, NK (120 kg N ha ${ }^{-1}$ plus $\left.118 \mathrm{~kg} \mathrm{~K} \mathrm{ha}^{-1}\right)$, and PK (40 kg P ha ${ }^{-1}$ plus $\left.118 \mathrm{~kg} \mathrm{~K} \mathrm{ha}^{-1}\right)$. Soil samples $(0-20 \mathrm{~cm})$ from each plot (size of $33 \mathrm{~m}^{2}$ ) were taken randomly in March 2005 with a soil sampler and then mixed as a representative sample. The soil was sieved $(<2$ $\mathrm{mm}$ ) and stored at $-20^{\circ} \mathrm{C}$ for DNA extraction and $4^{\circ} \mathrm{C}$ for other analyses. Selected characteristics of the soil samples are listed in Table 1.

2.2 Isolation, counting, and identification of the culturable microorganisms

The total numbers of culturable bacteria and fungi were determined as colony forming units (CFUs) on agar plates by dilution plate methods. Briefly, triplicate $10 \mathrm{~g}$ of each fresh sample were homogenized in $90 \mathrm{ml}$ of sterilized water and serially diluted. Aliquots $(0.1 \mathrm{ml})$ of the diluted suspension were spread on the beef extract peptone medium and Czapek's medium for the enumeration of bacteria and fungi, respectively (Xu and Zheng 1986). The CFUs on
Table 1 Selected properties of an upland red soil under different fertilization treatments for 16 years

\begin{tabular}{lcccc}
\hline Treatment & $\mathrm{pH}\left(\mathrm{H}_{2} \mathrm{O}\right)$ & $C_{\text {org }}\left(\mathrm{g} \mathrm{kg}^{-1}\right)$ & $C_{\text {mic }}\left(\mathrm{g} \mathrm{kg}^{-1}\right)$ & $\begin{array}{l}\text { Available P } \\
\left(\mathrm{mg} \mathrm{kg}^{-1}\right)\end{array}$ \\
\hline CON & 4.9 & 7.27 & 0.15 & 10.6 \\
Manure & 6.0 & 10.5 & 0.26 & 143.1 \\
Return & 5.5 & 7.51 & 0.16 & 10.7 \\
NPK & 5.1 & 6.43 & 0.13 & 16.6 \\
NP & 5.1 & 6.95 & 0.15 & 21.8 \\
NK & 4.7 & 4.70 & 0.05 & 1.1 \\
PK & 6.0 & 6.33 & 0.18 & 7.6 \\
\hline
\end{tabular}

each medium were counted after incubation at $25^{\circ} \mathrm{C}$. Plates that carried between 50 to 200 colonies were counted on day 3 and day 5 , and some of these plates were used for microbial taxonomic identifications. From those plates for isolation of culturable bacteria and fungi, the colonies which were considered as representative microbes among all seven different treatments were picked out and identified to genera according to the instructions of the Bergey's Manual of Determinative Bacteriology (Holt et al. 1994) and the Manual of Determinative Mycology (Wei 1979).

\subsection{Soil DNA extraction, PCR, and DGGE}

Soil DNA was extracted using the FastDNA ${ }^{\circledR}$ SPIN Kit for soil (Bio 101 Inc. USA) according to the manufacturer's instructions. For soil bacteria, polymerase chain reaction (PCR) conditions for primers F968-GC and R1401 (Nubel et al. 1996) were executed as follows. Briefly, 20 pmol of each primer, $10 \mathrm{nmol}$ of each deoxyribonucleotide triphosphate, $75 \mathrm{nmol}$ of $\mathrm{MgCl}_{2}, 5 \mu \mathrm{l}$ of $10 \times$ PCR buffer, 2.5 Units Taq polymerase, and about $10 \mathrm{ng}$ of template DNA were combined with $\mathrm{H}_{2} \mathrm{O}$ to a total volume of $50 \mu \mathrm{l}$ in a 0.5-ml tube. The PCR was programmed as follows: initial denaturation for $7 \mathrm{~min}$ at $95^{\circ} \mathrm{C} ; 35$ cycles each consisting of $30 \mathrm{~s}$ at $95^{\circ} \mathrm{C}, 1 \mathrm{~min}$ at $56^{\circ} \mathrm{C}$, and $2 \mathrm{~min}$ at $68^{\circ} \mathrm{C}$; and a final extension of $10 \mathrm{~min}$ at $68^{\circ} \mathrm{C}$. For soil fungi, the PCR system was similar to bacterial PCR except that its own primers were NS1 and Fung-GC (May et al. 2001).

The PCR programs were as follows: an initial denaturation for $7 \mathrm{~min}$ at $95^{\circ} \mathrm{C}$; 35 amplification cycles of denaturation $\left(95^{\circ} \mathrm{C}\right.$ for $\left.30 \mathrm{~s}\right)$, annealing $\left(57^{\circ} \mathrm{C}\right.$ for $\left.1 \mathrm{~min}\right)$ and extension $\left(72^{\circ} \mathrm{C}\right.$ for $\left.2 \mathrm{~min}\right)$; and a final extension of $10 \mathrm{~min}$ at $72^{\circ} \mathrm{C}$. A DGGE gel comprised of $6 \%$ acrylamide/ bisacrylamide (37.5:1), and 40-60\% denaturants for bacterial analysis and $10-30 \%$ denaturants for fungal analysis, respectively. The electrophoresis was run in a DCode Universal Detection System Instrument (Bio-Rad Laboratories, Hercules, CA, USA) at a constant temperature of $60^{\circ} \mathrm{C}$ for $7 \mathrm{~h}$ at $120 \mathrm{~V}$. After running, the gels were stained with 1:10,000 SYBR Gold Nucleic Acid Gel Stain 
(Invitrogen Molecular Probes, Eugene, USA) for $30 \mathrm{~min}$ according to the manufacturer's instructions, and then photographed with UV transillumination.

\subsection{DNA cloning, sequencing and phylogenetic tree construction}

The gel strips of some distinguished bands among all treatments were excised from the gels using a sterile $10-\mu 1$ pipette tip and transferred to $50 \mu \mathrm{l}$ of Tris- $\mathrm{HCl}(\mathrm{pH} 8.0)$. DNA was recovered from the gels by freeze-thawing more than three times. The recovered DNA was then used for a second PCR. The reamplification products were evaluated by DGGE to verify and correct mobility compared to the original DGGE gel. The excised and re-amplified bands, which in the DGGE rerun gels gave one band at the expected position, were chosen for the next cloning experiment. These PCR products were purified using the Agarose Gel DNA Purification Kit (TaKaRa Biotechnology, Dalian, China) prior to cloning. The cloning experiments were conducted following the instructions of the manufacturer of the pGEM-T Easy Vector (Promega, Madison, WI). The sequencing of the recombinant plasmid DNAs of the clone cells was performed using an ABI PRISM 3730 DNA analyzer (Sangon Biotechnology, Shanghai, China). The obtained sequences were manually proofread and corrected if necessary, edited, and aligned using BioEdit version 4.8.5. The sequences were then analyzed with the National Center for Biotechnology Information (NCBI) Blast program. The most similar GenBank sequences to the clones were extracted from the GenBank. The sequences with a similarity of greater than $98 \%$ were regarded as being of the same operational taxonomic units (OTUs). Phylogenetic analyses were conducted using MEGA version 3.0 and the neighborjoining tree was constructed using $p$-distance with 1,000 replicates to produce Bootstrap values.

\subsection{Nucleotide sequence accession numbers}

The obtained sequences were submitted to the GenBank database and assigned accession numbers for bacteria of EF033205-EF033246 and for fungi of DQ890195-DQ890207.

\section{Results}

3.1 Culturable bacterial and fungal quantities and composition

Both organic and chemical fertilizers caused a shift of the culturable bacterial and fungal CFUs. The largest bacterial CFUs were observed in the NPK treatment, which received balanced chemical fertilizers, while the lowest CFUs were found in the NK treatment (Table 2). Bacterial CFUs of the two organic fertilization treatments (Manure and Return) were significantly lower than that of CON. Similar to Manure and Return, the treatments of NP and PK were also lower than CON. The highest fungal CFUs were detected in the Manure treatment. There was no significant difference in the fungal CFUs among the treatments of NPK, PK, Return, NP, and CON. Thus, different fertilization treatments resulted in changes in the soil culturable bacterial and fungal CFUs, with NPK and Manure having the highest bacterial and fungal CFUs, respectively, and the NK treatment having the lowest bacterial and fungal CFUs.

Thirty three strains of bacteria and 43 strains of fungi were selected to determine the composition of culturable organism in the soil. The identified bacterial and fungal isolates were classified into 12 genera and 25 genera, respectively (Table 3). A percentage of $42.4 \%$ of the identified bacterial isolates were members of Arthrobacter, indicating that approximately half of the representative bacteria were affiliated to this genus. Specifically, there were fewer culturable bacterial genera in the organic and balanced chemical fertilizer treatments than in the $\mathrm{CON}$ and imbalanced chemical fertilizer treatments. The result of fungal identification revealed that Aspergillus was the most frequently occurring genus, which made up $23.3 \%$ of the total identified fungal isolates, followed by Penicillium and Mucor, which together contributed to another $23.3 \%$ of the total identified fungal isolates. All 25 identified fungal genera could be further classified into Zygomycetes, Sordariomycetes, Eurotiomycetes, Leotiomycetes, Hyphomycetes or Sirococcus. There were more culturable fungal genera in the organic fertilizer treatments than in the chemical fertilizer treatments; whereas there were fewer culturable bacterial genera in the organic fertilizer treatments than in the chemical fertilizer treatments.

Table 2 Bacterial and fungal colony formation units (CFUs) of the soil fertilization treatments by the plate counting method

\begin{tabular}{lcc}
\hline Treatment & $\begin{array}{l}\text { Bacteria } \\
\left(10^{7} \mathrm{CFUs} \mathrm{g}^{-1} \mathrm{dw}\right)\end{array}$ & $\begin{array}{l}\text { Fungi } \\
\left(10^{4} \mathrm{CFUs} \mathrm{g}^{-1} \mathrm{dw}\right)\end{array}$ \\
\hline CON & $5.38 \pm 1.42 \mathrm{~b}^{\mathrm{a}}$ & $9.32 \pm 1.14 \mathrm{~b}$ \\
Manure & $1.82 \pm 0.14 \mathrm{~d}$ & $16.9 \pm 0.34 \mathrm{a}$ \\
Return & $1.87 \pm 0.25 \mathrm{~d}$ & $10.8 \pm 0.41 \mathrm{~b}$ \\
NPK & $14.2 \pm 2.12 \mathrm{a}$ & $11.5 \pm 2.11 \mathrm{~b}$ \\
NP & $3.00 \pm 0.36 \mathrm{c}$ & $9.90 \pm 0.66 \mathrm{~b}$ \\
NK & $0.52 \pm 0.05 \mathrm{e}$ & $5.94 \pm 0.33 \mathrm{c}$ \\
PK & $2.25 \pm 0.25 \mathrm{~d}$ & $11.4 \pm 1.01 \mathrm{~b}$ \\
\hline
\end{tabular}

${ }^{\mathrm{a}}$ The following letters (a-e) indicate significant differences between treatments at $P<0.05$ 
Table 3 Representative bacterial and fungal genera identified by conventional culturing methods

\begin{tabular}{|c|c|c|}
\hline Treatment & Detected bacteria & Detected fungi \\
\hline $\mathrm{CON}$ & $\begin{array}{l}\text { Arthrobacter }(2)^{\text {a }}, \text { Corynebacterium, } \\
\text { Erwinia, Lactobacillus }\end{array}$ & Aspergillus, Penicillium (2), Rhizopus, Thamnidium \\
\hline Manure & Arthrobacter (3), Corynebacterium & $\begin{array}{l}\text { Arachniotus, Byssochlamys, Mortierella, Mucor, Rhizopus, } \\
\text { Sirococcus, Syncephalastrum, Verticillum }\end{array}$ \\
\hline Return & Arthrobacter (3), Azomonas, Cellulomonas & $\begin{array}{l}\text { Absidia, Acrocylindrium, Articulospora, Geniculosporium, } \\
\text { Scopulariopsis, Varicosporium }\end{array}$ \\
\hline NPK & Acinetobacter, Arthrobacter (2) & Aspergillus, Mucor, Penicillium (2), Thielavia \\
\hline NP & Arthrobacter (2), Mycobacterium, Zoogloea & Aspergillus (2), Endogone, Penicillium (2), Verticicladiella \\
\hline NK & $\begin{array}{l}\text { Corynebacterium, Erwinia (2), Kurthia, } \\
\text { Mycobacterium, Pseudomonas }\end{array}$ & $\begin{array}{l}\text { Aspergillus (3), Cephalosporium, Gliocladium, } \\
\text { Mucor, Oospora }\end{array}$ \\
\hline PK & $\begin{array}{l}\text { Alcaligenes, Arthrobacter (2), Cellulomonas, } \\
\text { Mycobacterium, Pseudomonas }\end{array}$ & Aspergillus (3), Blakeslea, Leptographium, Mucor \\
\hline
\end{tabular}

${ }^{a}$ The numbers in the parantheses indicate the amount of strains which had been detected

\subsection{DGGE profiles of the soil bacterial and fungal} communities

The DGGE profiles of the bacterial communities of the samples are shown in Fig. 1a. The Manure treatment (lane 2) showed a dramatic shift in bacterial community, with a greater complexity of the banding pattern than CON (lane 1), indicating that Manure promoted a higher soil bacterial diversity. In the Return, NPK, and NP treatments (lanes 3, 4 , and 5), visible differences were hardly observed in the DGGE profiles. There were obviously fewer bands detected in NK than in CON and several novel bands (band 36 40) were obtained in the NK treatment. Cluster analyses (Fig. 1b) based on the DGGE profile showed that NP, PK, and CON had a similar banding pattern and clustered together firstly, suggesting that the long-term application of NP and PK fertilizers had little effects on the soil bac- terial diversity. Return, NPK, and Manure clustered together in another sub-cluster and clearly distinguished from the NK treatment.

This could reflect that NK (P-deficiency) caused significant bacterial variation both in composition (CFUs) and diversity. In fact, the least soil available $\mathrm{P}$ of the NK treatment was ascertained in Table 1. The DGGE profiles of the fungal communities (Fig. 2a) also showed some variations among the treatments. In the two organic fertilizer treatments, more bands appeared in the higher denaturing part of the gel where high- $\mathrm{G}+\mathrm{C}$ bands resolved compared with CON, with several new bands (band 1 5) detected in these two treatments. Two strong bands (Fig. 2a, indicated by black arrow) appearing in CON could only be found in some of the chemical fertilizer treatments (NPK, $\mathrm{NP}$, and PK). Defining CON as the reference condition, according to similarity with $\mathrm{CON}$, the order of the
Fig. 1 a DGGE profile of bacterial 16S rRNA gene fragments of soil samples under different fertilization treatments and $\mathbf{b}$ cluster analysis of left DGGE banding patterns. Lanes: 1 CON, 2 Manure, 3 Return, 4 NPK, 5 NP, 6 NK, 7 PK. The small white triangles and numbers on each lane indicated the bands excised for further analysis
(A)

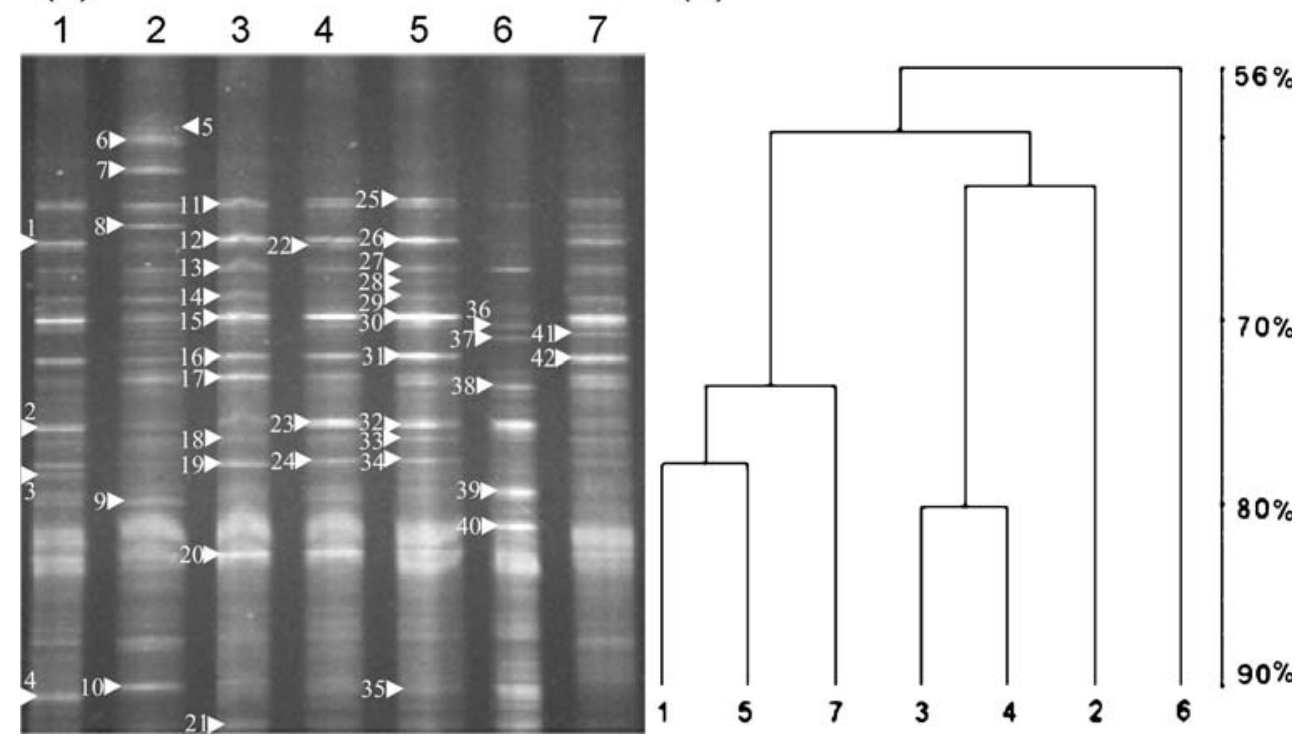


Fig. 2 a DGGE profile of fungal 18S rRNA gene fragments of soil samples under different fertilization treatments and $\mathbf{b}$ cluster analysis of left DGGE banding patterns. Lanes: 1 CON, 2 Manure, 3 Return, 4 NPK, 5 NP, 6 NK, 7 PK. The small white triangles and numbers on each lane indicated the bands excised for further analysis. The black arrows indicated two representative bands both of which were only detected in $\mathrm{CON}$ and some of the chemical fertilizer treatments (NPK, NP, and PK)

(A)

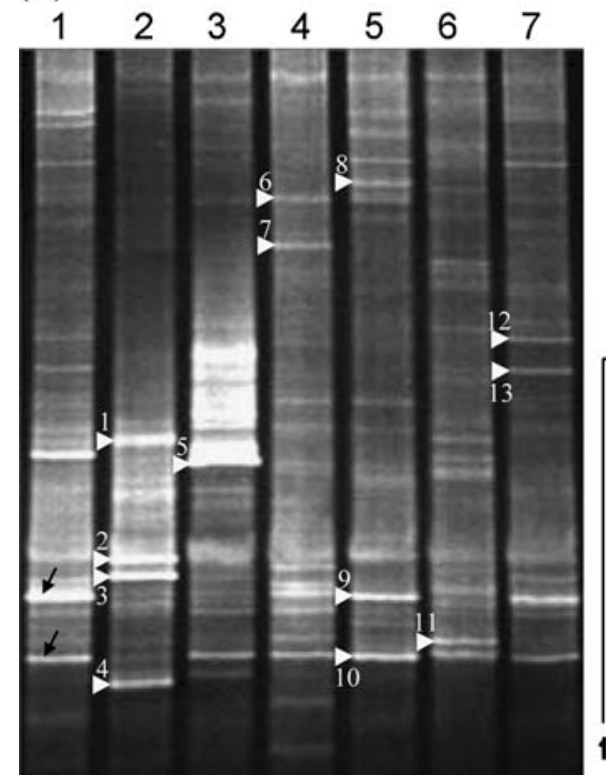

(B)

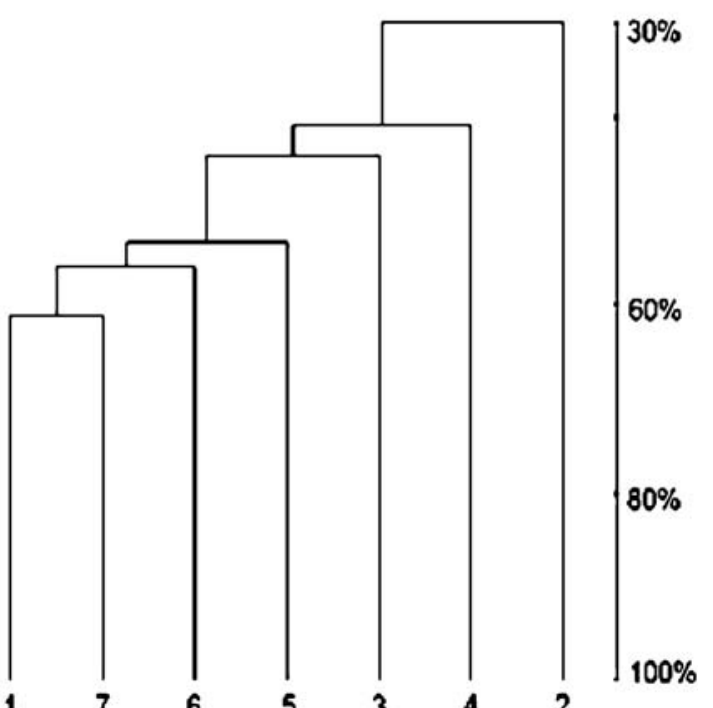

similarity values (from high to low) were PK, NK, NP, Return, NPK, and Manure (Fig. 2b).

\subsection{Phylogenetic analysis of 16S and 18S rRNA gene clones among the treatments}

Forty-two representative bacterial DGGE bands (numbering from 1 to 42) (Fig. 1a) and 13 fungal representative bands (numbering from 1 to 13) (Fig. 2a) were further analyzed. Three to five clones for each band were sequenced. Phylogenetic analysis of the bacterial 16S rRNA gene sequences showed that $74 \%$ of the clones were classified as Proteobacteria, in which $\gamma$-Proteobacteria had the greatest representation (48\%), followed by $\delta-, \alpha-$, and $\beta$-Proteobacteria (Fig. 3). Another 11 sequences were classified into Firmicutes, Actinobacteria, and Unclassified-bacteria. Fifteen of the 16S rDNA sequences related to $\gamma$-Proteobacteria were found in all seven fertilizer treatments, and sequences close to $\delta$-Proteobacteria appeared in all the treatments with the exception of NPK and PK treatments; six sequences which were affiliated with $\alpha$-Proteobacteria were predominant in the Return and NK treatments, and two sequences related to $\beta$-Proteobacteria appeared only in $\mathrm{CON}$ and NP. Sequences similar to Firmicutes were found in the CON, Manure, Return, and NP treatments, and Actinobacteria-like sequences appeared in the Return and NP treatments. Phylogenetic analysis of the fungal $18 \mathrm{~S}$ rRNA gene sequences showed that all sequences were divided into Tetracladium, Homobasidiomycetes, Pezizomycotina, Heterobasidiomycetes, and Pezizomycetes (Fig. 4). Sequences identified as Tetracladium were found in the NP and PK treatments; Homobasidiomycetes-like and Pezizomycotina-like sequences were only detected in the Return and NPK, respectively. Sequences affiliated with Heterobasidiomycetes were unique to the Return and NK; and Pezizomycetes-related sequences were only found in the Manure treatment.

\section{Discussion}

4.1 Bacterial and fungal composition and diversity as revealed by culture-dependent and culture-independent methods

Much higher bacterial diversity was observed in the soil tested using the culture-independent approaches than the culture-dependent approaches. In our culturing and taxonomic identification experiments, all of the isolates could be attributed to only four classes including $\gamma$-Proteobacteria, Actinobacteridae, $\beta$-Proteobacteria, and Firmicutes, while some other bacterial genera related to $\alpha$-Proteobacteria, $\delta$-Proteobacteria, Actinobacteria, and Unclassifiedbacteria only detected using the culture-independent methods. It is clear that a broader bacterial diversity was revealed from the same soil samples by using the cultureindependent method than the culture-dependent method. Moreover, the bacterial taxonomic classification revealed that the first largest cluster of isolates, dominated by Arthrobacter, represented significantly more isolates than any other bacterial genera.

However, partial 16S rRNA gene sequencing of 42 representative bands showed affiliation with seven bacterial divisions, and approximately $74 \%$ of them were affiliated with Proteobacter, indicating that Proteobacter is considered as a dominant bacterial genus in the soils tested by molecular methods. This is consistent with a previous study 


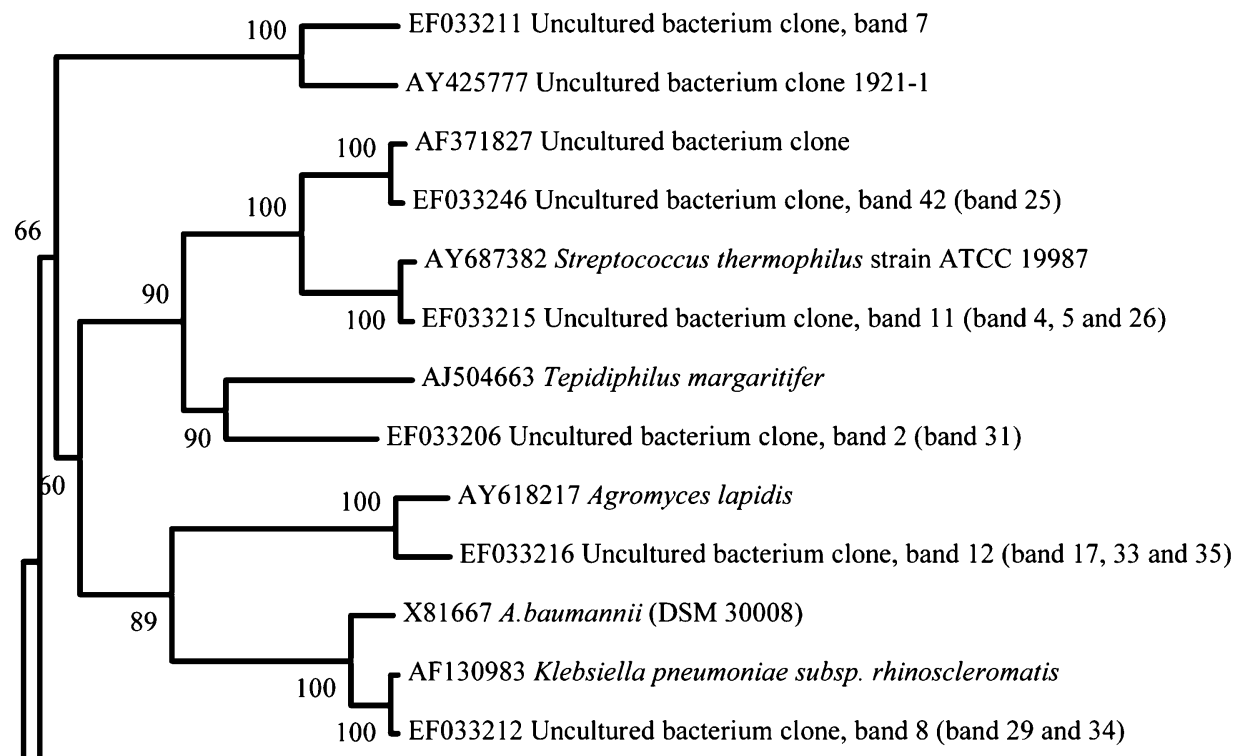

EF033228 Uncultured bacterium clone, band 24 (band 1, 22 and 23)

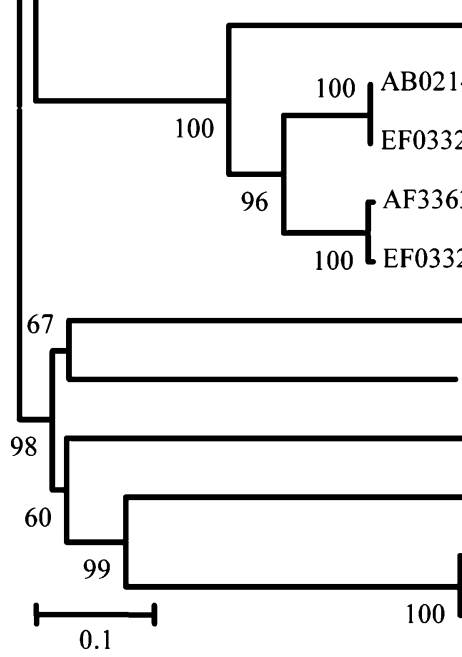

Fig. 3 Phylogenetic tree of bacterial 16S rRNA gene clone sequences from Yingtan upland red soil of China, including 42 sequences of excised bands from bacterial DGGE gel and 12 of their most similar GenBank sequences. The sequences, which were regarded as being of

of forest soil using cloning library methods (He et al. 2006). Therefore, different dominating bacterial genera were identified in the soil by using the culture-dependent versus the culture-independent methods. For the soil fungi in this study, Zygomycetes, Sordariomycetes, Eurotiomycetes, Leotiomycetes, Hyphomycetes, and Sirococcus were identified as the dominant fungal components by the culture-dependent method, while Tetracladium, Homobasidiomycetes, Heterobasidiomycetes, Pezizomycetes, Eurotiomycetes, and Leotiomycetes were the major fungal members revealed by the culture-independent method. Although Eurotiomycetes and Leotiomycetes were both detected by using the culturedependent and culture-independent methods, significant differences in fungal compositions were observed between these two research approaches.
Unclassified-bacteria

7

Firmicutes

]

$\beta$-proteobacteria

Actinobacteria

7

$V$-proteobacteria

$\alpha$-proteobacteria

\rceil$\delta$-proteobacteria the same OUT, are shown by their band numbers in parentheses following the representative sequence. Bootstrap values $(>50 \%)$ are indicated at branch points. The scale bar represents $10 \%$ estimated sequence divergence

In general, molecular methods were expected to give a more realistic view of species richness and distribution because only a certain fraction of the fungi in soil can be cultured (Smit et al. 1999). Vainio and Hantula (2000) showed that DGGE detected more fungal species than the culturing method from environment samples. However, the major limitation to generalized studies of soil fungi by purely molecular methods is the lack of discrimination in the technique between living and dead material, or active and dormant organisms (Bridge and Spooner 2001). Thus, it was deemed necessary to investigate soil fungi by estimating their CFUs and culturable genera to increase understanding of the soil fungi. Therefore, despite the fact that culture-dependent techniques are not ideal for studies of the composition of natural microbial communities when 


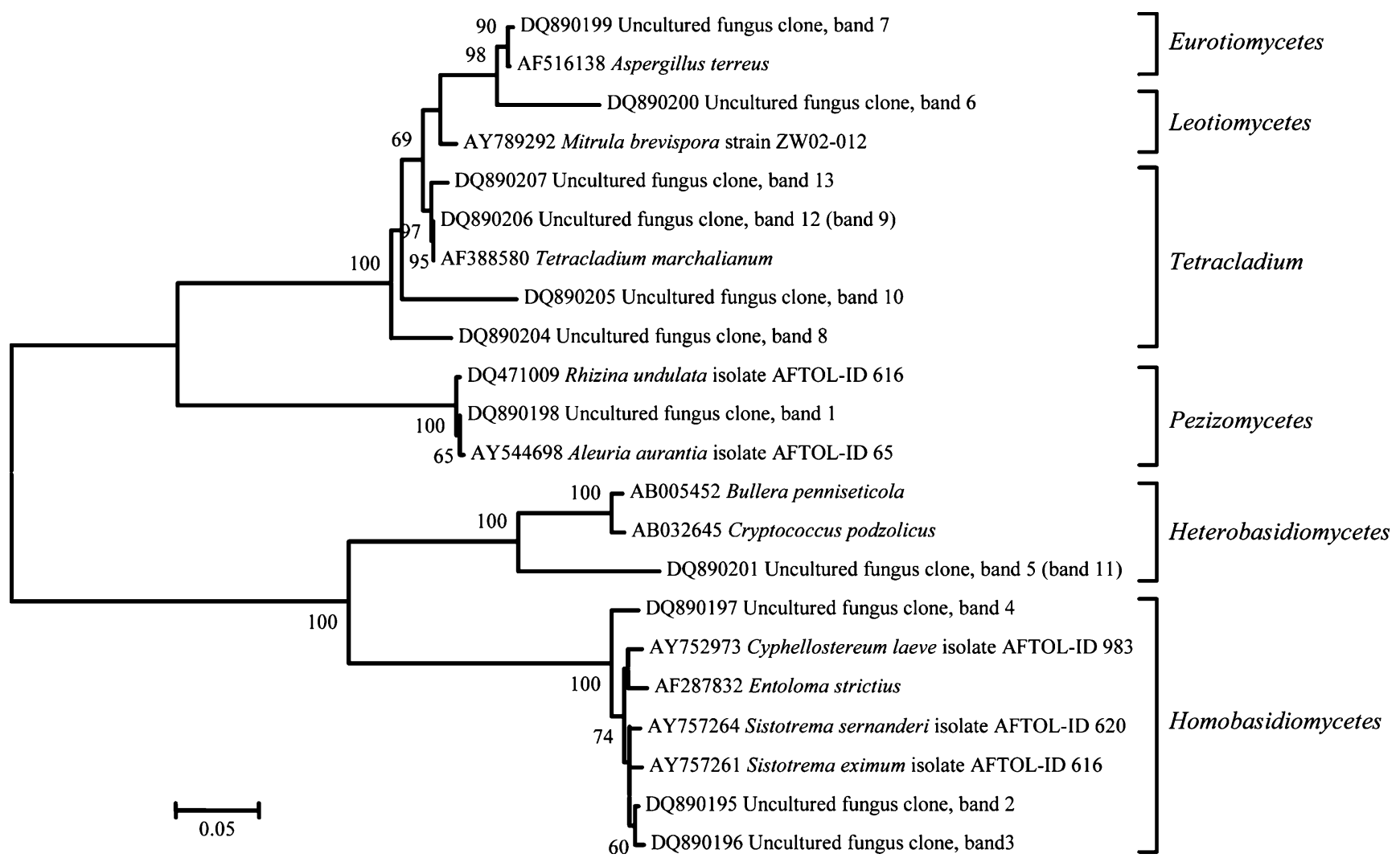

Fig. 4 Phylogenetic tree of fungal 18S rRNA gene clone sequences from Yingtan upland red soil of China, including 13 sequences of excised bands from fungal DGGE gel and 11 of their most similar GenBank sequences. The sequences, which were regarded as being of

used alone, they provide one of the more useful means of understanding the growth habit, development, and potential function of microorganisms from soil habitats. A combination of culture-dependent and culture-independent approaches is likely to reveal more complete information regarding the composition of soil microbial communities.

\subsection{Long-term effects of fertilization on soil bacterial and fungal communities}

Significant differences were found in bacterial CFUs and the identified representative genera among the different fertilization treatments based on the culture-dependent techniques. The bacterial CFUs were highest in the NPK and lowest in the NK treatment, suggesting that $\mathrm{P}$ deficiency might directly suppress the growth of culturable bacteria. A recent study showed that the average CFUs of soil bacteria and fungi in treatments with $\mathrm{P}$ were significantly greater than those in treatments without $\mathrm{P}$ (Zhong and Cai 2007). This was consistent with our results as bacterial and fungal counts changed strongly with/without $\mathrm{P}$ nutrient. In contrast to the NPK, the organic fertilizer treatments Manure and Return had much lower bacterial CFUs. One reason for this unexpected result could be some the same OUT, are shown by their band numbers in parentheses following the representative sequence. Bootstrap values $(>50 \%)$ are indicated at branch points. The scale bar represents $5 \%$ estimated sequence divergence

physical texture and (or) chemical nutrient elements in soil have changed during the long-term fertilization process.

In this study, we found that long-term fertilization had resulted in some shifts of basic soil characteristics including $\mathrm{pH}$, total $\mathrm{C}, \mathrm{N}$, and available $\mathrm{P}$ contents, and these changes could lead to significant microbial differences. Girvan et al. (2003) reported that soil type and its properties could be a dominant factor controlling the general microbial community composition. Soil total bacterial community composition could be more associated to the particle size fraction than the different organic amendments (Sessitsch et al. 2001). Another possible reason for interpreting this surprising result could be that during long-term (16 years) applications of organic fertilizers, the soil bacterial population would have shifted so that those species capable of using such fertilizers would thrive while some other species would have died out, thus leading to a less diverse population.

Some fungi (e.g., saprotrophic) play a major role in carbon and nutrient cycling in terrestrial ecosystems (Deacon et al. 2006) and are sensitive to disturbance, pollution, biofertilizers, and herbicides (Weissenhorn and Leyval 1996; Westergaard et al. 2001; Young 2006). Furthermore, some fungal species were also reported to be 
effective in the removal of arsenic in polluted soils (Cernansky et al. 2007). In our study, different fertilizer treatments caused distinct changes in soil fungal communities. A very notable finding was that fungal CFUs appeared maximal in the organic Manure treatment. This result, however, was inconsistent with bacterial CFUs in Manure, indicating that bacteria and fungi responded differently to the fertilization. Similar to bacteria, the minimum fungi CFUs were also observed in the NK treatment.

This result provided evidence that $\mathrm{P}$ could be a very vital component for soil microorganisms. In addition, after longterm fertilization application, it was evident that more representative fungal genera appeared in the organic treatments than other treatments, indicating that culturable fungi were more sensitive to the organic than to the chemical fertilizer treatments. The DGGE profile showed that the highest similarity value was found between CON and PK, indicating that the deficiency of $\mathrm{N}$ element had little effect on soil fungal community. However, in a previous study, we found that $\mathrm{N}$ element could be considered as a key factor in controlling soil bacterial community ( $\mathrm{Ge}$ et al. 2008). The physiology difference between soil bacteria and soil fungi, and also the different soil types may have resulted in this discrepancy.

Furthermore, in contrast to the three imbalanced chemical fertilization treatments (NP, NK, and PK), organic treatments (Manure and Return) and balanced chemical NPK treatment appeared to have a more dramatic effect on the fungal community. Overall, the DGGE results revealed that fungal communities responded to the organic fertilizer treatments more sensitively than to the imbalanced chemical fertilizer treatments.

\section{Conclusions}

Our results demonstrated that fertilization had great effects on the soil bacterial and fungal community. Organic fertilizer applications induced the least culturable bacterial CFUs but the highest bacterial diversity, while chemical fertilizer applications had less impact on soil bacterial composition and diversity. The largest fungal CFUs were obtained but much lower diversity was detected in the Manure treatment. The lowest bacterial and also fungal CFUs were observed in the NK treatment. The long-term fertilization treatments resulted in different bacterial and fungal compositions ascertained by the culture-dependent and also the culture-independent approaches.

In this study, P fertilizer could be considered as a key factor to control the microbial CFUs and diversity in a Chinese red soil. Soil fungi seem to be a more sensitive indicator of soil fertility than soil bacteria. Both culture- dependent and culture-independent molecular methods should be used to appropriately characterize microbial diversity in soil.

\section{Recommendations and perspectives}

Soil fungi seem to be a more sensitive indicator of soil fertility than soil bacteria. Since the major limitation of molecular methods in soil microbial studies is the lack of discrimination between the living and dead, or active and dormant microorganisms (Bridge and Spooner 2001), both culture-dependent and culture-independent methods should be used to appropriately characterize soil microbial diversity.

Acknowledgments This work was financially supported by the Chinese Academy of Sciences (KZCX2-YW-408, KZCX1-YW-603) and the Natural Science Foundation of China (50621804, 40571082).

\section{References}

Bridge P, Spooner B (2001) Soil fungi: diversity and detection. Plant Soil 232:147-154

Cai ZC, Qin SW (2006) Dynamics of crop yields and soil organic carbon in a long-term fertilization experiment in the Huang-HuaiHai Plain of China. Geoderma 136:708-715

Cernansky S, Urik M, Sevc J, Khun M (2007) Biosorption and biovolatilization of arsenic by heat-resistant fungi. Environ Sci Pollut Res 14:31-35

Davis KER, Joseph SJ, Janssen PH (2005) Effects of growth medium, inoculum size, and incubation time on culturability and isolation of soil bacteria. Appl Environ Microbiol 71:826-834

Deacon LJ, Pryce-Miller EJ, Frankland JC, Bainbridge BW, Moore PD, Robinson CH (2006) Diversity and function of decomposer fungi from a grassland soil. Soil Biol Biochem 38:7-20

Ellis RJ, Neish B, Trett MW, Best JG, Weightman AJ, Morgan P, Fry JC (2001) Comparison of microbial and meiofaunal community analyses for determining impact of heavy metal contamination. $\mathbf{J}$ Microbiol Methods 45:171-185

Ellis RJ, Morgan P, Weightman AJ, Fry JC (2003) Cultivationdependent and -independent approaches for determining bacterial diversity in heavy-metal-contaminated soil. Appl Environ Microbiol 69:3223-3230

Enwall K, Philippot L, Hallin S (2005) Activity and composition of the denitrifying bacterial community respond differently to longterm fertilization. Appl Environ Microbiol 71:8335-8343

Ge Y, Zhang JB, Zhang LM, Yang M, He JZ (2008) Long-term fertilization regimes and diversity of an agricultural affect bacterial community structure soil in northern China. J Soils Sediments 8:43-50

Girvan MS, Bullimore J, Pretty JN, Osborn AM, Ball AS (2003) Soil type is the primary determinant of the composition of the total and active bacterial communities in arable soils. Appl Environ Microbiol 69:1800-1809

He JZ, Xu ZH, Hughes J (2006) Molecular bacterial diversity of a forest soil under residue management regimes in subtropical Australia. FEMS Microbiol Ecol 55:38-47

He JZ, Shen JP, Zhang LM, Zhu YG, Zheng YM, Xu MG, Di HJ (2007) Quantitative analyses of the abundance and composition 
of ammonia-oxidizing bacteria and ammonia-oxidizing archaea of a Chinese upland red soil under long-term fertilization practices. Environ Microbiol 9:2364-2374

Herai Y, Kouno K, Hashimoto M, Nagaoka T (2006) Relationships between microbial biomass nitrogen, nitrate leaching and nitrogen uptake by corn in a compost and chemical fertilizeramended regosol. Soil Sci Plant Nutr 52:186-194

Holt JG, Krieg NR, Sneath PHA, Staley JT, William ST (1994) Bergey's manual of determinative bacteriology. Williams and Wilkins, Baltimore, USA

Karlen DL, Ditzler CA, Andrews SS (2003) Soil quality: why and how? Geoderma 114:145-156

Kennedy AC (1999) Bacterial diversity in agroecosystems. Agric Ecosyst Environ 74:65-76

Kirk JL, Beaudette LA, Hart M, Moutoglis P, Klironomos JN, Lee H, Trevors JT (2004) Methods of studying soil microbial diversity. J Microbiol Meth 58:169-188

Kostanjsek R, Lapanje A, Drobne D, Perovic S, Perovic A, Zidar P, Strus J, Hollert H, Karaman G (2005) Bacterial community structure analyses to assess pollution of water and sediments in the Lake Shkodra/Skadar, Balkan Peninsula. Environ Sci Pollut Res 12:361-368

Mallarino AP, Borges R (2006) Phosphorus and potassium distribution in soil following long-term deep-band fertilization in different tillage systems. Soil Sci Soc Am J 70:702-707

May LA, Smiley B, Schmidt MG (2001) Comparative denaturing gradient gel electrophoresis analysis of fungal communities associated with whole plant corn silage. Can J Microbiol $47: 829-841$

Muyzer G (1999) DGGE/TGGE a method for identifying genes from natural ecosystems. Curr Opin Microbiol 2:317-322

Muyzer G, Dewaal EC, Uitterlinden AG (1993) Profiling of complex microbial populations by denaturing gradient gel electrophoresis analysis of polymerase chain reaction-amplified genes coding for 16S rRNA. Appl Environ Microbiol 59:695-700

Nubel U, Engelen B, Felske A, Snaidr J, Wieshuber A, Amann RI, Ludwig W, Backhaus H (1996) Sequence heterogeneities of genes encoding 16S rRNAs in Paenibacillus polymyxa detected by temperature gradient gel electrophoresis. J Bacteriol 178:5636-5643

Palmroth MRT, Koskinen PEP, Pichtel J, Vaajasaari K, Joutti A, Tuhkanen TA, Puhakka JA (2006) Field-scale assessment of phytotreatment of soil contaminated with weathered hydrocarbons and heavy metals. J Soils Sediments 6:128-136

Pernes-Debuyser A, Tessier D (2004) Soil physical properties affected by long-term fertilization. Eur J Soil Sci 55:505-512

Ratcliff AW, Busse MD, Shestak CJ (2006) Changes in microbial community structure following herbicide (glyphosate) additions to forest soils. Appl Soil Ecol 34:114-124
Sessitsch A, Weilharter A, Gerzabek MH, Kirchmann H, Kandeler E (2001) Microbial population structures in soil particle size fractions of a long-term fertilizer field experiment. Appl Environ Microbiol 67:4215-4224

Shen JP, Zhang LM, Zhu YG, Zhang JB, He JZ (2008) Abundance and composition of ammonia-oxidizing bacteria and ammoniaoxidizing archaea communities of an alkaline sandy loam. Environ Microbiol 10:1601-1611

Simek M, Hopkins DW, Kalcik J, Picek T, Santruckova H, Stana J, Travnik K (1999) Biological and chemical properties of arable soils affected by long-term organic and inorganic fertilizer applications. Biol Fertil Soils 29:300-308

Smit E, Leeflang P, Glandorf B, van Elsas JD, Wernars K (1999) Analysis of fungal diversity in the wheat rhizosphere by sequencing of cloned PCR-amplified genes encoding 18S rRNA and temperature gradient gel electrophoresis. Appl Environ Microbiol 65:2614-2621

Thompson IP, Bailey MJ, Ellis RJ, Maguire N, Meharg AA (1998) Response of soil microbial communities to single and multiple doses of an organic pollutant. Soil Biol Biochem 31:95-105

Torsvik V, Daae FL, Sandaa RA, Ovreas L (1998) Novel techniques for analysing microbial diversity in natural and perturbed environments. J Biotechnol 64:53-62

Vainio EJ, Hantula J (2000) Direct analysis of wood-inhabiting fungi using denaturing gradient gel electrophoresis of amplified ribosomal DNA. Mycol Res 104:927-936

Vieira FCS, Nahas E (2005) Comparison of microbial numbers in soils by using various culture media and temperatures. Microbiol Res 160:197-202

Wei JC (1979) Manual of determinative mycology. Shanghai Science and Technology, Shanghai, China

Weissenhorn I, Leyval C (1996) Spore germination of arbuscular mycorrhizal fungi in soils differing in heavy metal content and other parameters. Eur J Soil Biol 32:165-172

Westergaard K, Muller AK, Christensen S, Bloem J, Sorensen SJ (2001) Effects of tylosin as a disturbance on the soil microbial community. Soil Biol Biochem 33:2061-2071

$\mathrm{Xu} \mathrm{GH}$, Zheng HY (1986) Handbook of analysis methods of soil microbiology. Agricultural, Beijing, China

$\mathrm{Xu} \mathrm{ZH}$, Chen CR (2006) Fingerprinting global climate change and forest management within rhizosphere carbon and nutrient cycling processes. Environ Sci Pollut Res 13:293-298

Young AL (2006) Enhanced co-metabolism of TCDD in the presence of high concentrations of phenoxy herbicides. Environ Sci Pollut Res 13:149-150

Zhong WH, Cai ZC (2007) Long-term effects of inorganic fertilizers on microbial biomass and community functional diversity in a paddy soil derived from quaternary red clay. Appl Soil Ecol 36:84-91 